\title{
PROSES DIFUSI INOVASI E-AGRIBUSINESS : REGOPANTES PADA END-USER KOMODITAS PERTANIAN DI JABODETABEK
}

\author{
Eki Yoan Meydora \\ Corporate Communication, STIKOM The London School of Public Relations \\ email: eymeidora@gmail.com
}

\begin{abstract}
This study analyzes the information dissemination process of RegoPantes, an e-agribusiness innovation to connect farmers to agricultural commodity users directly, thus cutting the long chain of distribution. RegoPantes is a platform developed by 8villages to help farmers receive fair price for every agricultural commodity they sell, with the aim to help improve the farmer welfare. The purpose of this study is to identify constraints faced by diffusion agencies that disseminate information about RegoPantes to the public specifically housewives as end users of agricultural commodities. This study uses descriptive qualitative methods to provide an in-depth understanding of the diffusion of RegoPantes. Data was collected through indepth interviews and document studies. Based on the result of research known that 8villages chose a public relations approach that included press relations in disseminating information about RegoPantes. Although there have been many publications from various media, the adoption of innovations by end users of agricultural commodities is still not optimal.
\end{abstract}

Keywords: e-agribusiness, agriculture, technology, innovation, diffusion of innovation, the process of diffusion of innovation

\section{PENDAHULUAN}

Sebagai negara agraris, inovasi pada kegiatan di sektor agrikultural menjadi suatu kebutuhan bagi Indonesia. Iqbal (2017) menyatakan bahwa pemanfaatan teknologi untuk pertanian yang dikenal dengan istilah agritech atau agricultural technology sudah berkembang selama lebih dari satu abad terakhir. Namun, yang membuat agritech saat ini berbeda yaitu environment business (iklim usaha). Iklim usaha yang sedang berkembang kini didominasi oleh teknologi informasi yang sangat kental. Hal ini ditunjukkan dengan kemunculan berbagai agritech berbasis teknologi informasi (Iqbal,2017).

Soekartawi (2007) menjelaskan bahwa teknologi informasi dan komunikasi yang memasuki kegiatan di sektor pertanian seperti proses produksi, panen, pasca panen, pemasaran dan kegiatan lainnya yang berkaitan dengan kegiatan pertanian adalah cikal bakal munculnya istilah e-agriculture atau $e$ - agribusiness. Oleh sebab itu, dapat dijelaskan bahwa $e$-agriculture atau e-agribusiness merupakan pemanfaatan teknologi internet pada sektor pertanian.

Latar belakang kemunculan e-agribusiness di Indonesia didorong dengan penggunaan internet yang masif di masyarakat. Berdasarkan data yang dirilis oleh Direktorat Jenderal Informasi dan Komunikasi Publik, Kementerian Komunikasi dan Informatika menunjukkan bahwa dengan total populasi penduduk sejumlah 262 juta jiwa, Indonesia memiliki 143,26 juta pengguna internet. Dengan kata lain, sebanyak $54,68 \%$ dari total jumlah penduduk Indonesia merupakan pengguna internet (Widiastuti, 2018).

Laporan yang dipublikasi oleh Dailysocial.id menunjukkan bahwa lanskap startup digital sebagai perusahaan rintisan yang mengembangkan inovasi e-business atau e-commerce dalam berbagai sektor terus berkembang, termasuk pada sektor $e$ - 
agribusiness (Startup Report 2017, 2018). Beberapa startup mengembangkan platform yang terdiri dari aplikasi dan website untuk memfasilitasi kegiatan $e$ agribusiness, diantaranya adalah Eragano, iGrow, 8Villages, SayurBox, Simbah, Pantau Harga, Karsa, Kecipir, TaniHub, Lima Kilo, Sikumis, Crowde, dan PanenID (Pratama, 2017).

Diantara start up tersebut, 8Villages merupakan satu-satunya start up pengembang e-agribusiness yang telah diakui secara internasional oleh Perserikatan Bangsa-Bangsa melalui International Telecommunications Union (ITU) untuk mendukung akselerasi pembangunan dan kemajuan sosial-ekonomi, khususnya perwujudan Agenda Pembangunan Berkelanjutan (Sustainable Development Goals/SDGs). Bentuk pengakuan tersebut diberikan melalui penghargaan PBB bagi inisiatif teknologi informasi dan komunikasi pada acara World Summit on the Information Society (WSIS) Prize 2017, yang dilaksanakan pada 12-16 Juni 2017 di Jenewa, Swiss (PBB Serahkan Penghargaan WSIS Prize, 2017).

Sebagai pengembang aplikasi yang fokus pada permasalahan di pedesaan, insiatif yang diusung 8 Villages telah berkontribusi dalam menghadirkan inovasi berupa e-agribusiness yaitu RegoPantes, sebuah platform niaga elektronik yang menjembatani transaksi langsung antara petani dengan pengguna akhir atau end user (Syarif, 2017). Perbedaan RegoPantes dengan e-agribusiness yang dikembangkan oleh startup lain adalah $e$ agribusiness ini memiliki fitur yang memungkinkan pengguna untuk memperoleh informasi detail mengenai petani yang dibeli hasil panennya (wawancara pra riset, Oktober 2017). Selain itu,
Kelebihan RegoPantes adalah platform ini menawarkan harga komoditas pertanian yang lebih murah dibandingkan di pasar modern serta kesegaran prima karena waktu panen sampai rumah hanya dalam waktu 24 jam (Hidayat, 2017).

RegoPantes berasal dari bahasa Jawa yang berarti harga pantas. Sesuai dengan namanya, RegoPantes memberikan harga pantas untuk setiap komoditas pertanian yang diproduksi oleh petani (Santhika, 2018). Melalui RegoPantes petani langsung bertindak sebagai penjual, dimana komoditas pertanian yang akan dipanen dalam waktu dekat diposting melalui aplikasi RegoPantes langsung oleh petani (wawancara pra riset, 2017).

Bekerjasama dengan pemerintah provinsi Jawa Tengah, 8villages meluncurkan RegoPantes kepada petani pada 23 September 2017 di Magelang dengan disaksikan langsung oleh Menteri Pertanian, Andi Amran Sulaiman (Pribadi, 2017). Pasca peluncuran, dilakukan rangkaian sosialisasi cara menggunakan aplikasi RegoPantes kepada petani (Handayani, 2017). Sebulan pasca diluncurkan kepada petani, pada 23 Oktober 2017 8Villages berkolaborasi dengan BNI meluncurkan RegoPantes di Jakarta kepada end user termasuk ibu rumah tangga sebagai pengguna komoditas pertanian (Primus, 2017).

Tiga bulan setelah diluncurkan di Jakarta yaitu pada Januari 2018, baik website maupun aplikasi RegoPantes telah diakses oleh 8.004 pembeli dan 2.847 petani yang saling terkoneksi. Dengan transaksi yang berhasil dilakukan melalui RegoPantes adalah sebanyak $5.715 \mathrm{~kg}$ hasil tani dari Magelang, Batang, Brebes, dan Wonogiri (Kusdiantono, 2018). 
Dalam memperkenalkan platform RegoPantes, 8Villages mengusung gerakan "Membeli Itu Membantu". Melalui gerakan tersebut, 8Villages menghimbau masyarakat agar lebih menghargai kerja keras para petani. Melalui gerakan \#MembeliituMembantu, RegoPantes mengajak publik untuk peduli pada petani dan masalah pertanian di Indonesia. Gerakan ini menyuarakan bahwa dengan membeli komoditas hasil pertanian melalui RegoPantes, bukan semata-mata merupakan tindakan pemenuhan kebutuhan fisik melainkan juga memiliki nilai sosial berupa kepedulian terhadap kesejahteraan petani di Indonesia (RegoPantes.com menghubungkan petani, 2017).

8villages mengklaim selain untuk kesejahteraan petani, gerakan tersebut juga menguntungkan dari sisi pembeli karena RegoPantes menawarkan harga komoditas pertanian yang lebih murah dibandingkan harga di pasar modern (Wulandari, 2017).

Berdasarkan penjelasan mengenai RegoPantes, maka pengguna inovasi e-agribusiness ini meliputi petani sebagai penyedia komoditas pertanian dan ibu rumah tangga sebagai end user atau pengguna akhir komoditas pertanian tersebut. Pada penelitian ini yang menjadi fokus utama yaitu pengguna akhir komoditas pertanian yaitu ibu rumah tangga yang memiliki kebiasaan pergi ke pasar dan berbagai gerai yang menjual komoditas pertanian untuk memenuhi kebutuhan akan sayur dan buah serta komoditas hasil tani lainnya.

Penelitian ini akan melihat bagaimana 8Villages sebagai salah satu startup yang mengembangkan $e$ agribusiness dalam memperkenalkan dan menyebarkan informasi mengenai RegoPantes sebagai sebuah inovasi untuk membantu ibu rumah tangga sebagai end user dalam memperoleh komoditas pertanian. Selain itu penelitian ini juga akan menganalisa kendala-kendala apa saja yang dihadapi 8Villages dalam menyebarluaskan informasi mengenai inovasi yang ditawarkan (RegoPantes) agar dapat diterima dan diadopsi oleh ibu rumah tangga, yang sudah terbiasa memenuhi kebutuhan akan buah dan sayur dengan membeli langsung kepada pedagang. Bagaimanakah 8 Villages menangani kendala-kendala tersebut juga akan dibahas pada penelitian ini.

Jawaban dari pertanyaan-pertanyaan tersebut penting untuk diketahui, agar inovasi 8Villages dengan menghadirkan e-agribusiness yaitu RegoPantes dapat terus berkembang guna membantu meningkatkan kesejahteraan petani di pedesaan sesuai dengan misinya.

\section{METODOLOGI PENELITIAN}

Penelitian ini menggunakan metode penelitian kualitatif deskriptif untuk menginvestigasi dan menggambarkan serta memberi pemahaman mengenai proses difusi inovasi e-agribusiness, RegoPantes, pada ibu rumah tangga. Metode penelitian ini dapat membantu memahami proses tersebut dengan menganalisa pandangan ibu rumah tangga yang berbeda-beda terhadap inovasi baru yang ditawarkan.

Metode penelitian kualitatif dipilih berdasarkan penjelasan Daymon dan Holloway (2008, p. 4) bahwa metode penelitian ini memiliki kemampuan yang baik untuk menghasilkan pemahaman dari perspektif para stakeholder, sehingga memungkinkan peneliti untuk melihat berbagai hal sebagaimana dilihat oleh para pelakunya. 
Adapun informan pada penelitian ini terdiri dari Wilda Romadhona, Head of RegoPantes, Dickson Leo, public relations consultant yang membantu 8Villages dalam mengkomunikasikan RegoPantes, serta ibu rumah tangga sebagai penerima inovasi. Ibu rumah tangga yang dipilih untuk membantu memperoleh data pada penelitian ini memiliki kriteria yaitu wanita yang sudah menikah dengan usia 25 - 50 tahun, dan tinggal di sekitar daerah Jabodetabek, serta sudah pernah membeli komoditas pertanian melalui RegoPantes.

Dalam penelitian ini, pengumpulan data dilakukan peneliti melalui wawancara mendalam. Selain pengumpulan data sekunder dilakukan melalui studi literatur termasuk buku, artikel jurnal, berita di berbagai media, juga dokumen terkait topik penelitian, seperti data mengenai 8 Villages di berbagai media baik cetak maupun elektronik.

Teknik analisis data yang digunakan pada penelitian ini adalah interaktif model yang dikemukakan oleh Miles dan Huberman. Teknik analisis ini menurut Pawito (2008, p.104) pada dasarnya terdiri dari komponen-komponen yaitu reduksi data, data display, pengambilan keputusan dan verifikasi. Dalam penelitian ini penulis menggunakan teknik pemeriksaan keterpercayaan data yaitu triangulasi sumber, dimana peneliti memeriksa keterpercayaan data melalui beberapa sumber data baik primer maupun sekunder.

Penelitian ini dimulai pada bulan Maret 2018 September 2018. Dalam jangka waktu tersebut, peneliti mendapatkan informasi mendalam dari informan. Tempat penelitian disesuaikan dengan ketersediaan informan.

\section{HASIL DAN PEMBAHASAN}

Severin dan Tankard (2001, p.247) menyimpulkan bahwa riset difusi merupakan penelitian proses sosial mengenai bagaimana inovasi-inovasi sosial (ide, praktik, dan objek baru) menjadi diketahui dan tersebar ke sistem sosial. Sesuai dengan pengertian tersebut, riset difusi inovasi e-agribusiness yang dilakukan oleh peneliti akan menganalisis bagaimana inovasi eagribusiness yaitu RegoPantes menjadi diketahui dan tersebar kepada ibu rumah tangga sebagai bagian dari sistem sosial.

Sebagai perusahaan yang menawarkan inovasi baru dalam bidang teknologi pertanian, 8villages melakukan difusi inovasi atau penyebarluasan informasi mengenai e-agribusiness, RegoPantes. Berdasarkan pernyataan Head of RegoPantes yakni Wilda Romadhona, tujuan difusi inovasi yang dilakukan oleh 8villages adalah untuk meningkatkan jumlah pengadopsi atau pengguna RegoPantes.

Dalam proses difusi inovasi, terdapat istilah change agent atau agen perubahan. Severin dan Tankard (2001, p.251) menjelaskan bahwa change agent atau agen perubahan adalah seorang profesional yang berusaha untuk memengaruhi keputusan adopsi dalam arah yang menurutnya dikehendaki. Severin dan Tankard lebih lanjut menjelaskan bahwa change agent berperan sebagai perwakilan dari perusahaan yang mempromosikan inovasi kepada pengadopsi potensial.

Berdasarkan wawancara yang telah dilakukan change agent yang berperan dalam penyebaran informasi mengenai RegoPantes yaitu divisi-divisi yang dipimpin oleh Wilda Romadhona selaku Head of RegoPantes. Selain itu, penyebaran informasi 
juga dilakukan oleh pihak ketiga yaitu sebuah public relations agency. Pada penelitian ini pihak ketiga tersebut diwakili oleh Dickson Leo, selaku public relations consultant yang membantu aktivitas komunikasi 8villages dengan media.

Everett. M. Rogers (1983, p.11-24) mengungkapkan elemen-elemen yang terdapat pada difusi inovasi meliputi inovasi, saluran komunikasi, waktu dan sistem sosial. Berikut ini akan dijelaskan secara mendalam keempat elemen difusi inovasi pada penelitian mengenai teknologi baru dibidang pertanian e-agribusiness ini.

\section{Inovasi}

Rogers (1983,p.11) mendefinisikan inovasi sebagai sebuah ide, praktek, atau objek yang dianggap baru oleh individu atau unit lain yang mengadopsinya. Selain itu, menurut Rogers (1983, p.138) kata "teknologi" sering digunakan untuk menyatakan inovasi.

E-agribusiness adalah wujud peran teknologi informasi dan komunikasi yang telah merambah kegiatan pertanian (Soekartawi, 2007). Di Indonesia e-agribusiness mulai berkembang sejak tahun 2016, ditandai dengan mulai diluncurkannya inovasi ini oleh para penggiat startup, dan berkembang hingga menjadi tren start up pada tahun 2017 (Jeko, 2017). Para penggiat start up menawarkan inovasi berupa e-agribusiness sebagai pasar online yang menghadirkan berbagai komoditas pertanian kepada end user atau pengguna akhir. Berdasarkan penjelasan tersebut dapat dinyatakan bahwa $e$ agribusiness tergolong baru berkembang di masyarakat terutama ibu rumah tangga pada saat ini.
Menurut Rogers (1983, p.135) proses perkembangan inovasi terdiri dari keputusan, aktivitas, dan dampak yang terjadi akibat dari identifikasi kebutuhan atau masalah melalui penelitian, pengembangan, dan kommersialisasi sebuah inovasi, melalui difusi dan adopsi inovasi tersebut oleh pengguna.

Berikut ini akan dijelaskan tahapan perkembangan inovasi e-agribusiness, RegoPantes, sebelum diluncurkan kepada publik secara khusus ibu rumah tangga sebagai end user.

a. Kesadaran terhadap Masalah atau Kebutuhan

Wilda Romadhona selaku Head of RegoPantes mengungkapkan masalah yang menjadi perhatian 8villages hingga akhirnya mengembangkan RegoPantes sebagai solusi yaitu adanya ketidakadilan harga, baik di tingkat konsumen, maupun di tingkat petani. Misalnya pada saat lebaran tahun 2017, harga cabai di tingkat petani hanya tiga belas ribu, sedangkan harga cabai di Jakarta sekitar tujuh puluh hingga delapan puluh ribu.Terdapat ketimpangan harga yang cukup jauh.

Ketimpangan harga ini yang melatarbelakangi 8villages mencari solusi dalam bentuk inovasi untuk menghubungkan petani dengan pengguna akhir secara langsung sehingga petani dapat memperoleh harga pantas dari setiap komoditas pertanian yang dijual.

Selain data primer yang diperoleh dari hasil wawancara, peneliti juga melakukan studi dokumen untuk memperoleh informasi mengenai latar belakang RegoPantes dikembangkan. Terdapat sebuah artikel pada media online yang mendeskripsikan bagaimana founder of 
RegoPantes, Wim Prihanto termotivasi untuk mengembangkan inovasi ini.

Pada tahun 2015, harga jahe merah sedang turun membuat petani di lereng Gunung Sewu, Jawa Tengah, enggan untuk panen. Kondisi itu disampaikan oleh salah seorang teman kepada Wim Prihanto. Wim kemudian menawarkan ide untuk menjual jahe ke industri di daerah Solo, namun ditolak karena harga yang juga tidak bagus (Wulandari, 2018).

Berdasarkan penjelasan founder of RegoPantes maupun Head of RegoPantes tersebut maka dapat disimpulkan bahwa masalah utama yang menjadi perhatian e-agribusiness ini adalah ketimpangan harga komoditas pertanian yang diperoleh petani dan dibayarkan oleh pembeli. Petani mendapatkan harga yang tidak layak untuk komoditas yang ditanam.

\section{b. Penelitian}

RegoPantes merupakan hasil karya dari penelitian terapan (applied research) tanpa melalui penelitian dasar (basic research). Hal ini disampaikan oleh Wim Prihanto, founder of RegoPantes pada kutipan media online bahwa pasca ide untuk menjual jahe ke industri di daerah Solo ditolak karena harga yang juga tidak bagus, Wim mengusulkan ide lain sebagai solusi untuk memasarkan jahe yaitu dengan mengadakan sebuah acara penjualan dengan harga yang pantas atau berkeadilan, Argo Fair Price. Hasilnya, dalam waktu dua minggu, event itu bisa menjual 250 kilogram (kg) jahe dengan harga pantas (Wulandari,2018).
Pemasaran jahe merah tersebut merupakan bentuk validasi ide Wim Prihanto bahwa gagasan untuk membeli sekaligus membantu petani dapat dilakukan bersamaan. Wim selaku pelaksana kegiatan memberikan harga yang pantas, tidak terlalu kecil bagi petani tetapi juga tidak tinggi kepada konsumen (Wulandari, 2018).

Penjelasan tersebut juga dikonfirmasi oleh Head of RegoPantes pada wawancara yang telah dilakukan, bahwa pada awalnya sudah ada prototipe bisnis secara offline selama dua tahun sejak 2015, yang dicoba ke konsumen juga kepada petani.

Ternyata membawa hasil yang positif untuk kedua belah pihak.

Berdasarkan penjelasan tersebut maka dapat disimpulkan bahwa RegoPantes berangkat dari penelitian terapan dengan tujuan untuk memecahkan masalah sosial. Acara Argo Fair Price merupakan wujud penerapan model bisnis secara offline sebagai bentuk validasi ide bisnis sebelum diterapkan secara online.

\section{c. Pengembangan}

Pada tahap pengembangan, ide bisnis baru yang sudah divalidasi selama dua tahun tersebut dikembangkan menjadi platform yang terdiri dari website dan aplikasi, seperti yang diungkapkan oleh Head of RegoPantes dalam wawancara maupun founder of RegoPantes dalam kutipan artikel di media. Ide bisnis tersebut dikembangkan dalam bentuk aplikasi untuk petani, dimana petani dapat memposting sendiri komoditas pertanian yang ingin dijual, dan website untuk pengguna membeli komoditas pertanian. 8villages merupakan pengembang baik aplikasi maupun website RegoPantes. 


\section{d. Komersialisasi}

Komersialisasi e-agribusiness RegoPantes terjadi pada saat proses pengerjaan model bisnis RegoPantes dari offline menjadi online yang dilakukan oleh 8villages sejak RegoPantes bergabung pada April 2017 (Wulandari, 2017). 8villages merupakan start up yang berperan sebagai perancang website dan aplikasi RegoPantes termasuk design visual sebelum digunakan oleh petani dan end user.

\section{e. Difusi Inovasi}

Pada proses perkembangan inovasi, menurut Rogers (1983, p. 144) tahap yang paling penting adalah keputusan untuk mulai menyebarkan inovasi kepada pengadopsi potensial atau dikenal dengan istilah difusi. 8villages memutuskan untuk mulai menyebarkan informasi mengenai RegoPantes kepada publik melalui dua kegiatan, yaitu peluncuran RegoPantes pada 23 September 2017 kepada petani di Magelang, Jawa Tengah (Primus, 2017), dan peluncuran RegoPantes kepada end user di Jakarta pada 23 Oktober 2017 bekerjasama dengan salah satu bank pemerintah yang juga menjadi penerbit Kartu Tani, BNI (Primus, 2017).

Sejak diluncurkan kepada pengguna akhir atau end user, melalui laman regopantes.com, publik dan petani dihubungkan secara langsung untuk melakukan transaksi komoditas pertanian. Berdasarkan wawancara yang dilakukan peneliti dengan Head of RegoPantes, agensi difusi yang digunakan 8villages untuk menyebarkan informasi mengenai RegoPantes sebagai inovasi baru di bidang pertanian meliputi pihak internal yaitu tim 8villages yang bertanggungjawab untuk divisi RegoPantes dan pihak eksternal yaitu sebuah public relations consultant yang membantu kegiatan komunikasi RegoPantes dengan media.

Selanjutnya akan dijelaskan secara mendalam, bagaimana cara 8villages dan agensi difusi tersebut melakukan difusi inovasi atau menyebarkan informasi mengenai RegoPantes kepada publik termasuk pengadopsi potensial melalui berbagai kegiatan komunikasi dengan media massa maupun melalui komunikasi interpersonal.

\section{f. Konsekuensi}

Berdasarkan data yang diperoleh peneliti, pada Oktober 2017 terdapat 850 petani yang mengunduh aplikasi RegoPantes (Primus, 2017). Jumlah ini meningkat signifikan pada bulan Desember 2017 menjadi 2.847 petani (Kusdiantono,2018). Peningkatan jumlah juga terjadi pada end user atau pengguna akhir. Pada Oktober 2017, jumlah end user yang terdaftar mencapai 4.500 (Primus, 2017). Pada bulan Desember 2017, total jumlah end user yang terdaftar megalami peningkatan menjadi 8.004 (Kusdiantono, 2018).

Berdasarkan data diatas maka dapat dinyatakan bahwa selama dua bulan beroperasi, terdapat penambahan jumlah petani sebanyak 1.997 petani yang terdaftar di RegoPantes. Sedangkan, jumlah pengguna akhir meningkat sebanyak 3.504 pengguna yang terdaftar. Lonjakan yang signifikan terhadap jumlah pengguna RegoPantes baik petani maupun end user komoditas pertanian tersebut membuktikan bahwa konsekuensi dari inovasi yang ditawarkan 8villages berupa e-agribusiness telah dapat memecahkan masalah dilihat dari antusias petani maupun pengguna.

\section{Saluran Komunikasi}


Rogers (1983, p.198) mengkategorikan dua saluran komunikasi yang dapat digunakan untuk mengkomunikasikan ide atau inovasi baru kepada publik. Kedua saluran komunikasi tersebut yaitu media massa dan komunikasi interpersonal. Berikut ini akan dijelaskan dua saluran komunikasi yang dimanfaatkan 8villages dalam mengkomunikasikan RegoPantes sebagai inovasi baru untuk publik secara khusus ibu rumah tangga.

\section{a. Media Massa}

Dalam menggunakan media massa, 8villages dibantu oleh sebuah public relations consulant, seperti yang diungkapkan oleh Head of RegoPantes pada wawancara. Oleh sebab itu, peneliti juga melakukan wawancara dengan public relations consultant yang membantu kegiatan komunikasi 8villages. Dickson Leo selaku public relations consultant 8 villages, menyampaikan bahwa sebagai pihak ketiga yang ditunjuk untuk membantu kegiatan komunikasi RegoPantes, pihaknya telah melakukan berbagai kegiatan atau aktivitas komunikasi.

Pada wawancara yang telah dilakukan, Dickson Leo menjelaskan bahwa sebagai public relations consultant RegoPantes, pihaknya membantu kegiatan atau aktivitas komunikasi yang merupakan bagian dari press relations. Hubungan dengan media atau press relations menurut Ruslan (2016,p. 167) merupakan alat pendukung untuk kepentingan publikasi dan publisitas berbagai kegiatan program kerja untuk kelancaran aktivitas komunikasi dengan pihak publik. Berdasarkan penjelasan mengenai kegiatan press relations atau hubungan dengan media tersebut, maka dapat disimpulkan bahwa tujuan utama press relations adalah untuk menghasilkan publisitas.

Kegiatan-kegiatan untuk menghasilkan publisitas yang telah dilakukan oleh public relations consultant RegoPantes meliputi konferensi pers, wawancara pers, press interview, press briefing, special events, dan feature articles. Berdasarkan data media monitoring, sejak awal diluncurkan kepada publik pada Oktober 2017 hingga Agustus 2018, RegoPantes telah mendapatkan sebanyak 135 artikel media melalui berbagai kegiatan atau aktivitas press relations sebagai berikut.

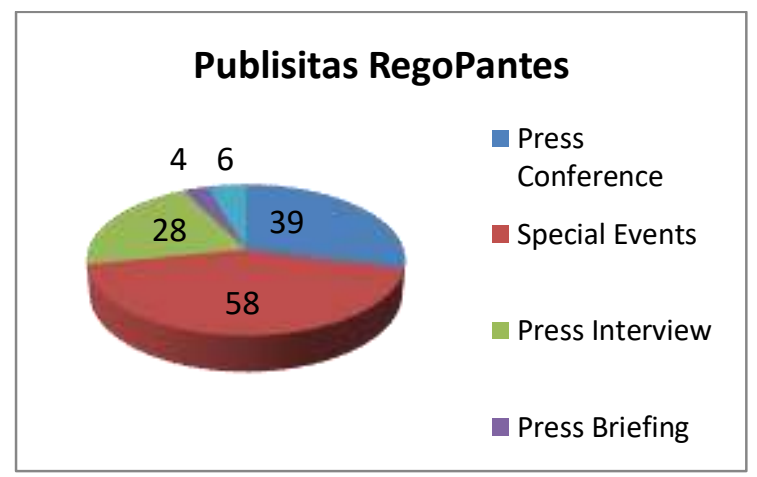

Dari kegiatan komunikasi tersebut, special events menyumbang artikel terbanyak yaitu 58 artikel. Pada wawancara yang telah dilakukan, public relations consultant yang membantu kegiatan komunikasi RegoPantes dengan media menyampaikan bahwa untuk mengkomunikasikan RegoPantes digunakan beragam media termasuk media cetak (koran dan majalah), serta media online.

Sejak diluncurkan kepada pengguna akhir pada Oktober 2017, RegoPantes mendapatkan total publisitas dari media cetak maupun online sebanyak 135 artikel terdiri dari 124 artikel dari media online dan 11 artikel dari surat kabar, dengan rincian sebagai berikut. 


\section{Publisitas RegoPantes Okt 2017 - Agust 2018}

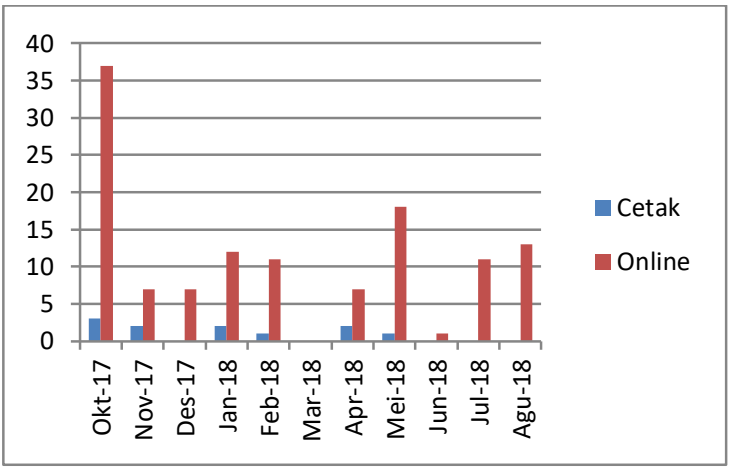

RegoPantes memperoleh publisitas pada media online setiap bulan kecuali pada bulan Maret 2018. Namun hingga Agustus 2018, RegoPantes tidak mendapatkan publisitas media cetak pada beberapa bulan termasuk Desember 2017, Maret, Juni, Juli, dan Agustus 2018.

Adapun, publisitas terbanyak diperoleh RegoPantes pada bulan Oktober 2017 yaitu sebanyak 37 artikel pada saat platform eagribusiness ini diluncurkan kepada publik melalui kegiatan press conference. Berdasarkan data media monitoring tersebut dapat disimpulkan bahwa RegoPantes mendapatkan lebih banyak publisitas di media online dibandingkan media cetak.

Banyaknya publisitas yang diperoleh RegoPantes baik dari media cetak maupun online ternyata tidak menjangkau seluruh ibu rumah tangga sebagai end user. Hal ini dapat dilihat dari total delapan ibu rumah tangga sebagai end user yang telah diwawancarai peneliti, tidak satu pun yang pernah membaca atau melihat berita mengenai RegoPantes di surat kabar.

Namun, media online berperan dalam menyediakan informasi tambahan kepada pengguna potensil. Dari delapan informan yang telah menggunakan RegoPantes, seorang ibu rumah tangga mencari informasi tambahan mengenai RegoPantes melalui media online. Hal ini membuktikan pernyataan Ruben dan Steward (2014, p. 208) bahwa media massa berfungsi untuk memperkuat pesan.

Selain media cetak dan online, RegoPantes juga memperoleh publisitas dari televisi. Menurut Elvinaro dan Erdinaya (2005, p.128) fungsi televisi sama dengan fungsi media massa lainnya, namun fungsi menghibur lebih dominan pada media televisi, selanjutnya untuk memperoleh informasi. Beberapa televisi yang pernah menayangkan berita tentang RegoPantes termasuk Jawa Pos TV dalam program talkshow Beranda dan TV One dalam program Coffee Break.

Dalam mengkomunikasikan RegoPantes, 8villages juga memanfaatkan beberapa media sosial yaitu facebook, instagram, youtube, dan twitter. Pada media sosial ini RegoPantes menginformasikan berbagai komoditas pertanian yang tersedia serta manfaatnya, juga profil petani yang telah bergabung di RegoPantes, special event yang sedang diikuti RegoPantes, termasuk juga resep-resep sederhana yang dapat dicoba. Tim RegoPantes aktif menggunakan media sosial ini untuk berkomunikasi dengan pengadopsi potensial atau end user komoditas pertanian. Testimoni end user komoditas pertanian yang telah mendapatkan komoditas pertanian dari RegoPantes juga tersedia di instagram yaitu pada fitur instastory.

Media sosial lain yang digunakan RegoPantes adalah facebook. Konten yang terdapat pada media sosial ini kurang lebih sama seperti pada instagram. Kelebihan facebook ialah terdapat fitur toko, dimana publik dapat melihat komoditas pertanian 
yang dijual RegoPantes serta harganya. Selain itu juga terdapat fitur ulasan dan rekomendasi, dimana publik dapat memberikan komentar tentang $e$ agribusiness ini.

Berdasarkan analisa peneliti, tim RegoPantes tidak aktif menggunakan media sosial twitter. Hal ini dapat dilihat dari postingan terakhir yaitu pada 14 September 2017. Saat ini, jumlah followers twitter RegoPantes hanya 171.

RegoPantes juga memiliki account Youtube yang berisi enam video termasuk video peluncuran website RegoPantes dan cerita petani. Subscriber Youtube ini hanya 14. Adapun video yang paling banyak ditonton yaitu sebanyak 479 adalah video RegoPantes - Launching Story.

Berdasarkan analisa peneliti, dari keempat media sosial yang digunakan RegoPantes, instagram merupakan yang paling populer. Hal ini dapat dilihat dari jumlah followers yang sudah mencapai 3.572, paling banyak diantara media sosial lainnya. Selain itu, dari wawancara yang telah dilakukan peneliti, beberapa informan menyebutkan bahwa mereka mengetahui keberadaan RegoPantes pertama kali dari media sosial yaitu instagram.

Dari delapan orang informan yang diwawancarai peneliti, lima diantaranya mengetahui keberadaan RegoPantes dari instagram. Selain mengetahui dari instagram ada pula yang mencari informasi tambahan mengenai RegoPantes di instagram. Berdasarkan pernyataan-pernyataan tersebut, maka dapat disimpulkan bahwa media sosial instagram dapat menjangkau target publik lebih banyak dibandingkan dengan media sosial lainnya dan media massa yang meliputi media cetak dan online. Selain mengetahui keberadaan
RegoPantes dari instagram, end user yaitu dalam hal ini ibu rumah tangga juga mencari informasi lebih mendalam mengenai inovasi e-agribusiness ini melalui media sosial tersebut.

b. Komunikasi Interpersonal

Rogers (1983, p.18) menjelaskan saluran interpersonal lebih efektif dalam mempersuasi audience untuk mengadopsi ide atau inovasi yang ditawarkan. Saluran komunikasi interpersonal yang digunakan oleh RegoPantes adalah melalui chat personal via whatsapp.

Berdasarkan laporan Cheetah Data dari divisi big data Cheetah Mobile, WhatsApp masih menjadi pilihan nomor satu aplikasi social messenger yang digunakan oleh netizen Indonesia (Fauzi, 2017). Oleh sebab itu, pemilihan whatsapp sebagai saluran komunikasi interpersonal RegoPantes merupakan hal yang tepat.

Selain sebagai saluran komunikasi whatsapp juga dimanfaatkan untuk melayani pengguna inovasi yang mengalami kesulitan dalam melakukan pemesanan komoditas pertanian.

Berdasarkan pernyataan ibu rumah tangga dalam wawancara yang telah dilakukan, saluran komunikasi interpersonal melalui whatsapp diminati oleh ibu rumah tangga karena dianggap mempermudah proses pemesanan.

\section{Waktu}

Waktu adalah elemen penting dalam proses difusi. Beberapa dimensi waktu yang perlu diperhatikan dalam proses difusi termasuk dalam proses pengambilan keputusan dimana seorang individu beranjak dari pengetahuan akan inovasi 
menuju keputusan untuk mengadopsi atau mengabaikannya, relatifitas inovasi diadopsi lebih awal atau terlambat (Rogers, 1983, p.20).

Berdasarkan wawancara yang dilakukan peneliti dengan pengguna RegoPantes, diperoleh informasi bahwa pengguna inovasi tertarik untuk menggunakan RegoPantes setelah mereka mencari informasi lebih detail mengenai inovasi ini. Jadi jarak dimana seorang individu beranjak dari pengetahuan menuju keputusan untuk mengadopsi inovasi melalui tahap pencarian informasi yang lebih detail mengenai inovasi e-agribusiness tersebut.

Menurut Rogers (1983, p. 213 - 232) terdapat beberapa atribut inovasi yang berhubungan dengan relatifitas inovasi diadopsi lebih awal atau terlambat. Dari kelima atribut tersebut, keuntungan relatif, kecocokan, kemampuan untuk dicoba, dan kemampuan untuk diamati oleh sistem sosial berhubungan dengan tingkat kecepatan adopsi (rate of adoption) suatu inovasi. Sedangkan kerumitan tidak berhubungan dengan tingkat adopsi inovasi tersebut. Berikut ini adakan dijelaskan empat atribut inovasi yang berhubungan dengan kecepatan adopsi e-agribusiness RegoPantes.

\section{a. Keuntungan Relatif}

Rogers (1983, p. 213) menyatakan bahwa keuntungan relatif dapat dilihat dari sejauh mana sebuah inovasi dianggap sebagai ide yang lebih baik dari yang digantikannya. Tingkat keuntungan relatif ini sering dinyatakan dalam bentuk profitabilitas ekonomi, status sosial, dan lainnya.

Pada wawancara yang telah dilakukan peneliti, Head of RegoPantes menjelaskan keuntungan- keuntungan yang ditawarkan RegoPantes termasuk traceability (RegoPantes mencantumkan nama petani, lokasi lahan, anggota kelompok tani apa, tanggal panen kapan sehingga pengguna dapat melacak informasi tersebut), proses yang transparan baik di sisi konsumen maupun di sisi petani, dan gratis ongkos kirim. Berdasarkan wawancara yang dilakukan peneliti dengan ibu rumah tangga diperoleh informasi bahwa keuntungan secara ekonomi seperti yang diungkapkan oleh Rogers tidak menjadi atribut inovasi utama pada RegoPantes. Keuntungan yang menarik bagi pengadopsi inovasi adalah traceability dan transparansi.

\section{b. Kecocokan}

Rogers (1983, p.223) mengungkapkan bahwa compatibility merupakan tingkat kecocokan suatu inovasi terhadap nilai-nilai yang ada, pengalaman, dan kebutuhan pengadopsi potensial. Sebuah ide yang cocok berarti sudah lebih pasti untuk pengadopsi potensial. Sebuah inovasi dapat cocok atau tidak dengan sosial budaya dan kepercayaan, ide yang sudah ada, atau dengan kebutuhan akan inovasi tersebut.

Berdasarkan pengamatan peneliti, nilai-nilai yang dibawa oleh RegoPantes sesuai dengan nilai sosial yang terdapat pada masyarakat dalam hal ini ibu rumah tangga. Hal tersebut dinyatakan oleh ibu rumah tangga pada wawancara yang dilakukan peneliti, bahwa misi sosial yang dibawa oleh RegoPantes yaitu Membeli itu Membantu memiliki kecocokan dengan nilai-nilai sosial yang ada. Nilai sosial tersebut adalah membantu meringankan beban petani dengan membeli komoditas langsung dari petani. 


\section{c. Trialibility}

Menurut Rogers (1983, p.231) trialibility adalah kemampuan suatu inovasi dapat diujicoba secara terbatas. Cara yang dipilih 8villages agar pengguna potensial dapat mencoba RegoPantes secara terbatas adalah melalui promosi berupa kode voucher yang diberikan pada saat acara tertentu.

\section{d. Observability}

Rogers (1983, p.232) menjelaskan bahwa observability adalah bagaimana hasil dari suatu inovasi dapat dilihat oleh orang lain. Dari hasil pengamatan peneliti, pada media sosial instagram RegoPantes terdapat end user yang telah menerima komoditas pertanian yang memposting di instagram miliknya. Postingan tersebut berupa foto sayur dan buah disertai caption dan mention ke instagram RegoPantes. Postingan tersebut dapat dilihat dan diamati oleh orang lain.

Selain dengan menggunggah foto komoditas pertanian dan menandai RegoPantes, cara lain untuk mengamati e-agribusiness ini adalah melalui fitur instagram story. Pada fitur ini, pengguna RegoPantes juga menggunggah komoditas pertanian yang telah diperoleh langsung dari petani.

Berdasarkan penjelasan mengenai atribut yang berpengaruh pada keputusan untuk menggunakan inovasi RegoPantes, terdapat tiga atribut yang menonjol yaitu keuntungan, kecocokan, dan kemampuan untuk diamati. Dalam rasio pengadopsian inovasi di dalam sebuah sistem sosial, dihitung berapa jumlah anggota dalam sistem yang mengadopsi inovasi pada kurun waktu tertentu (Rogers, 1983,p.20).
Data yang diperoleh peneliti menunjukkan bahwa pada bulan Juni 2018 atau dalam kurun waktu delapan bulan setelah diluncurkan kepada pengguna potensial di Jakarta, pengguna RegoPantes mencapai 1.389. Sedangkan petani yang aktif menggunakan RegoPantes untuk menjual hasil panennya berjumlah 3.907 (Tumiwa, 2018). Jumlah pengguna akhir atau end user masih terlalu sedikit dibandingkan dengan jumlah petani yang sudah aktif menjual komoditas pertanian yang ditanam di RegoPantes.

\section{Sistem Sosial}

Pada teori difusi inovasi, masyarakat dipandang sebagai sebuah sistem sosial yang sangat besar. Kaitannya dengan penelitian ini yaitu ibu rumah tangga merupakan bagian dari masyarakat. Oleh sebab itu, ibu rumah tangga merupakan bagian dari sistem sosial yang menjadi fokus perhatian peneliti. Selain itu, ibu rumah tangga juga berperan sebagai pengambil keputusan dalam hal pembelian kebutuhan pangan.

Pertimbangan pemilihan ibu rumah tangga yang tinggal di Jabodetabek sebagai target publik dijelaskan oleh Consultant Public Relations 8villages bahwa bagian dari masyarakat sebagai sistem sosial yang dipilih 8villages sebagai target publik untuk RegoPantes adalah ibu rumah tangga yang tinggal di wilayah Jakarta, Bogor, Depok, Tangerang, dan Bekasi.

Berdasarkan data ibu rumah tangga yang diwawancarai peneliti telah menggunakan RegoPantes, dapat disimpulkan bahwa pengadopsi inovasi e-agribusiness RegoPantes memiliki pendidikan yang cukup tinggi yaitu S1. Selain 
berprofesi sebagai ibu rumah tangga, pengadopsi inovasi juga bekerja pada berbagai profesi.

Rogers (1983, p.248 - 250) mengelompokkan pengadopsi inovasi menjadi beberapa bagian. Berdasarkan analisa peneliti, informan yang telah diwawancarai termasuk kategori innovators dan early adopters. Menurut Rogers, innovators merupakan kelompok yang berani dan suka berpetualang mencoba ide baru meskipun mengetahui kemungkinan terjadinya resiko (Rogers, 1983, p.248). Ibu rumah tangga yang mengetahui RegoPantes dari instagram, mencoba menggunakan inovasi ini, meskipun mengetahui bahwa terdapat resiko-resiko yang mungkin terjadi.

Sedangkan, early adopters memiliki pengaruh yang cukup tinggi sehingga kelompok ini dimanfaatkan untuk mempercepat proses difusi (Rogers, 1983, p.249). Ibu rumah tangga ini juga dikelompokkan kedalam early adopters karena meskipun inovasi ini belum terlalu populer, namun mereka sudah menggunakannya.

\section{Proses Keputusan Inovasi}

Rogers (1983, p.163) menjelaskan bahwa proses pengambilan keputusan inovasi merupakan tahapan saat seorang individu melalui pengetahuan akan inovasi, membentuk sikap terhadap inovasi tersebut, hingga keputusan untuk mengadopsi atau menolak untuk mengimplementasikan inovasi, dan mengkonfirmasi keputusan tersebut. Berikut ini akan dijelaskan tahapan pada proses keputusan inovasi RegoPantes.

\section{a. Pengetahuan}

Ruslan (2016,p.167) menyatakan hubungan dengan media atau pers dapat sebagai saluran (channel) dalam penyampaian pesan maka upaya peningkatan pengenalan (awareness) dan informasi atau pemberitaan dari pihak sumber informasi merupakan prioritas utama. Hal tersebut karena salah satu fungsi pers adalah kekuatan pembentuk opini (power of opinion) yang sangat efektif melalui media massa.

Pengetahuan mengenai inovasi e-agribusiness yaitu RegoPantes disebarkan melalui berbagai media termasuk media massa atau pers dan media sosial yang dikelola oleh RegoPantes. Berdasarkan wawancara yang dilakukan oleh peneliti, lima dari delapan orang ibu rumah tangga yang diwawancarai mengetahui keberadaan RegoPantes dari media sosial instagram. Sedangkan sisanya mengetahui RegoPantes secara langsung melalui teman.

Berdasarkan temuan tersebut, maka dapat disimpulkan bahwa media sosial dapat digunakan dalam membentuk awareness end user pada $e$ agribusiness ini. Selain itu, saluran komunikasi interpersonal juga berperan penting dalam tahap menyebarkan pengetahuan akan inovasi.

\section{b. Persuasif}

Pada tahap persuasi dalam proses pengambilan keputusan, seorang individu membentuk sikap baik atau tidak baik terhadap inovasi. Menurut Rogers (1983, p.169), pembentukan sikap tersebut tidak selalu mengarah langsung kepada keputusan adopsi atau menolak inovasi. Aktivitas mental pada tahap pengetahuan merupakan kognitif, namun tipe pemikiran utama pada fungsi persuasif adalah afektif (perasaan).

Berdasarkan informasi yang peneliti peroleh dari hasil wawancara, setelah mengetahui keberadaan 
inovasi RegoPantes, pengguna potensial kemudian mencari informasi lebih detail melalui media online, website, dan instagram. Terdapat beberapa hal yang membuat pengguna potensial ini memutuskan untuk menggunakan RegoPantes, diantaranya adalah misi sosial yang terdapat pada RegoPantes, pengguna dapat mengetahui dari mana asal komoditas pertanian yang dibeli, dan petani siapa yang dibantu.

Faktor-faktor tersebut sesuai dengan apa yang disampaikan oleh Rogers yaitu tipe pemikiran utama pada fungsi persuasif adalah perasaaan.

Berdasarkan wawancara yang dilakukan peneliti dengan ibu rumah tangga sebagai end user maka dapat disimpulkan bahwa pesan persuasif yang diusung RegoPantes, Membeli itu Membantu, dapat diterima dan menjadi salah satu pertimbangan end user dalam menggunakan RegoPantes. Selain misi sosial tersebut, keuntungan-keuntungan yang ditawarkan seperti kesegaran prima, kualitas komoditas pertanian dan kemudahan pemesanan menjadi pertimbangan lainnya.

\section{c. Keputusan}

Pada tahap ini, individu menimbang keuntungan dan kerugian dari inovasi tersebut serta memutuskan untuk mengadopsi atau menolak inovasi yang ditawarkan (Rogers, 1983, p.173). Berdasarkan data yang diperoleh peneliti dari wawancara, selain pengadopsi inovasi terdapat pula yang menolak RegoPantes.

Berdasarkan wawancara yang dilakukan peneliti dengan Head of RegoPantes, dapat disimpulkan bahwa terjadi penolakan terhadap RegoPantes yang dilakukan oleh ibu yang tidak dekat dengan teknologi dan tidak mengetahui isu atau masalah pertanian.

\section{d. Implementasi}

Tahap ini terjadi ketika individu memilih untuk mengadopsi inovasi yang ditawarkan, dengan mencoba menerapkan inovasi tersebut (Rogers, 1983, p.174). Dalam mengadopsi RegoPantes, terdapat dua pilihan yang ditawarkan yaitu membeli melalui website atau melalui whatsapp. Dari wawancara yang telah dilakukan oleh peneliti, tujuh dari delapan informan lebih memilih menggunakan whatsapp karena lebih mudah dan praktis. Selain itu, tim RegoPantes secara aktif menawarkan komoditas pertanian melalui whatsapp setiap minggunya.

Dalam menggunakan RegoPantes, informan yang diwawancarai peneliti mengaku tidak menemukan kesulitan, karena dilayani dengan whatsapp meskipun ada yang masih melakukan pemesanan langsung melalui website. Namun, Head of RegoPantes menyatakan bahwa masih ada pengguna pemula yang kesulitan melakukan pemesanan.

Oleh sebab itu, dapat dinyatakan bahwa terdapat pengguna pemula RegoPantes atau yang baru pertama kali mencoba yang menghadapi kesulitan, namun untuk pengguna lainnya operasional RegoPantes dapat dikatakan mudah untuk diimplementasikan.

\section{e. Konfirmasi}

Pada tahap konfirmasi, individu (unit pengambilan keputusan lainnya) mencari penguatan atau pembenaran atas keputusan yang telah dibuat. Perlu diwaspadai, seseorang mungkin akan berbalik 
arah dari keputusan mengadopsi inovasi jika menemukan sesuatu yang tidak sesuai atau bertentangan tentang inovasi (Rogers, 1983, p.184).

Berdasarkan hasil wawancara yang dilakukan peneliti dengan kedelapan ibu rumah tangga pengguna RegoPantes, semuanya menyatakan puas dengan pelayanan yang diberikan oleh RegoPantes dan mereka akan terus menggunakan inovasi baru di bidang pertanian ini. Selain itu, para ibu rumah tangga ini juga mengkonfirmasi bahwa mereka merekomendasikan RegoPantes kepada teman dan keluarga.

\section{PENUTUP}

Sebagai sebuah inovasi baru di bidang pertanian, e-agribusiness dalam hal ini RegoPantes diharapkan dapat menjadi solusi untuk mengurai rantai distribusi yang panjang diantara petani dan ibu rumah tangga selaku pengguna akhir komoditas pertanian. Proses difusi inovasi atau penyebaran informasi mengenai RegoPantes dimulai saat 8villages memutuskan untuk menyebarkan informasi mengenai kehadiran RegoPantes kepada publik melalui peluncuran inovasi baru ini kepada petani di Jawa Tengah pada 23 September 2017, kemudian dilanjutkan dengan peluncuran kepada pengguna potensial pada 23 Oktober 2017 di Jakarta.

Dengan dibantu oleh sebuah agensi difusi yaitu public relations consultant, 8villages melakukan berbagai kegiatan media sebagai bagian dari proses difusi inovasi RegoPantes. Kegiatan media tersebut meliputi press conference, special events, media interview, dan editorial visit. Sejak diluncurkan kepada publik, RegoPantes telah memperoleh sejumlah publisitas dari berbagai media termasuk media online, cetak dan elektronik.

Namun, berdasarkan penelitian yang telah dilakukan, media sosial yaitu instagram adalah media yang paling banyak menjangkau ibu rumah tangga sebagai pengguna akhir komoditas pertanian. Pesan sosial "Membeli itu Membantu" yang diusung RegoPantes berpengaruh dalam mempersuasi ibu rumah tangga untuk menggunakan atau mengadopsi inovasi ini. Selain itu, keuntungan yang ditawarkan RegoPantes berupa kesegaran komoditas pertanian dan transparansi identitas petani juga mampu mempersuasi ibu rumah tangga untuk menggunakan RegoPantes.

Meskipun berbagai upaya difusi inovasi telah dilakukan baik melalui media massa maupun saluran komunikasi interpersonal, RegoPantes masih menghadapi penolakan oleh sebagian ibu rumah tangga. Dari data yang diperoleh, RegoPantes diadopsi oleh sedikit target publik sementara petani yang aktif berkontribusi jumlahnya lebih banyak. Berdasarkan analisa peneliti, terdapat satu elemen penting pada teori difusi inovasi yang tidak digunakan secara maksimal oleh 8villages dalam proses difusi inovasi RegoPantes yaitu opinion leader.

Adapun agensi difusi baik internal maupun eksternal tidak menemukan kendala dalam mengkomunikasikan RegoPantes melalui media massa maupun media sosial. Kendala yang dihadapi terdapat pada karakteristik sebagian end user yang menolak informasi karena dianggap kompleks.

Penelitian ini dapat menjadi referensi untuk perusahaan pengembang inovasi serupa dalam menentukan saluran komunikasi untuk melakukan 
penyebaran informasi mengenai e-agribusiness. Peneliti menyarankan agar perusahaan menggunakan lebih banyak saluran komunikasi interpersonal yang memfasilitasi terjadinya komunikasi tatap muka antara perusahaan dengan target publik.

Beberapa yang dapat dipertimbangkan seperti bekerja sama dengan komunitas wanita melakukan kegiatan kreatif contohnya cooking class dengan memanfaatkan bahan baku dari RegoPantes. Selain itu, peneliti menyarankan perusahaan untuk menggunakan opinion leader yang dapat membantu meningkatkan pengetahuan publik terhadap RegoPantes. Walaupun RegoPantes fokus pada instagram, sebaiknya media sosial lain seperti facebook dan twitter juga diperbaharui kontennya untuk menarik lebih banyak perhatian publik.

\section{DAFTAR PUSTAKA}

Ardianto, E., \& Erdinaya, L.K. (2005). Komunikasi Massa : Suatu Pengantar. Bandung : Simbiosa Rekatama Media

Daymond, C. \& Holloway, I. (2008).

Qualitative Research Method in Public

Relations and Marketing

Communications. Yogyakarta : Bentang

Fauzi, M.P. (2017). Whatsapp Youtube BBM Siapa yang Paling Populer di Indonesia. Diperoleh dari https://techno.okezone.com/read/2017/0 9/29/207/1785603/whatsapp-youtubebbm-siapa-yang-paling-populer-diindonesia

Handayani, R. (2017, Oktober 25).Teknologi yang menyejahterakan petani. Republika. p. 15

Hidayat, F. (2017, Oktober 23). Platform RegoPantes Hubungkan Petani dengan Konsumen. Beritasatu.com. Diperoleh dari :

http://www.beritasatu.com/bisnis/45962 2-platform-regopantes-hubungkanpetani-dengan-konsumen.html

Iqbal, M. (2017, Mei 29). FinTech, AgriTech, dan PropTech. Hidayatullah.com.

Diperoleh dari :

https://www.hidayatullah.com/kolom/ila hiyah-

finance/read/2017/05/29/117552/fintechagritech-dan-proptech.html

Jeko. ( 2017, Mei 8). Tren Startup Indonesia Didominasi Sektor Pertanian dan Kesehatan. Liputan6.com. Diperoleh dari :

https://www.liputan6.com/tekno/read/29 45029/tren-startup-indonesiadidominasi-sektor-pertanian-dankesehatan

Kusdiantono, Y. (2018, Januari 12). 8Villages berdayakan petani dengan IT. Koran Sindo. p. 20

Pawito .(2008). Penelitian Komunikasi Kualitatif. Yogyakarta : LKis Pelangi Aksara PBB Serahkan Penghargaan WSIS Prize 2017 pada Indonesia di Jenewa. (2017, Juni 15).

Presidentpost.id. Diperoleh dari : http://old.presidentpost.id/2017/06/15/pb b-serahkan-penghargaan-wsis-prize2017-pada-indonesia-di-jenewa/

Pratama,A.H. (2017, November 2016). Kumpulan Startup dan Aplikasi Pertanian di Indonesia. Techinasia. Diperoleh dari : https://id.techinasia.com/kumpulanemstartupem-dan-aplikasi-pertanian-diindonesia

Pribadi, B. \& Amanda, G. (2017, September 23). Mentan Kagumi Aplikasi RegoPantes Pemprov Jawa Tengah. Republika. Diperoleh dari : http://www.republika.co.id/berita/ekono $\mathrm{mi} / \mathrm{makro} / 17 / 09 / 23 /$ owq60e423-mentan- 
kagumi-aplikasi-regopantes-pemprovjawa-tengah

Primus, J. (2017, Oktober 23). Kartu Tani jadi Syarat Bisnis E-commerce.

Kompas.com. Diperoleh dari :

https://ekonomi.kompas.com/read/2017/ 10/23/193121226/kartu-tani-jadi-syaratbisnis-e-commerce

Rogers, E. M. (1983). Diffusion of Innovations. New York, NY: The Free

RegoPantes.com menghubungkan petani. (2017, Oktober 24). Warta Kota.

Diperoleh dari :

http://wartakota.tribunnews.com/2017/1 0/24/regopantescom-menghubungkanpetani-dengan-konsumen-meretasdelapan?page $=3$

Ruben, B.D., \& Steward, L.P.(2014). Komunikasi dan Perilaku Manusia. Jakarta : Rajawali Pers

Ruslan, R.(2016). Manajemen Public Relations dan Media Komunikasi : Konsepsi dan Aplikasi. Jakarta : Rajawali Pers

Santhika, Eka. (2018, Januari 14). RegoPantes layanan jual beli buah segar langsung dari petani. CNNIndonesia. Diperoleh dari :

https://www.cnnindonesia.com/teknologi /20180104163813-185-

266750/regopantes-layanan-jual-belibuah-segar-langsung-dari-petani

Severin,W.J.,\& Tankard, J.W. (2001). Teori

Komunikasi : Sejarah, Metode, \&

Terapan di Dalam Media Massa. Jakarta

: Prenada Media
Soekartawi. (2007, Juni 16). e-Business : Teori dan Aplikasinya. Seminar Nasional Aplikasi Teknologi Informasi (p.19-25). Yogyakarta, Indonesia

Startup Report 2017. (2018). Diperoleh dari : https://dailysocial.id/report/post/startupreport-2017

Syarif, M. (2017, Oktober 24). Platform RegoPantes Jembatani Petani dengan Konsumen. Neraca.id. Diperoleh dari : http://www.neraca.co.id/article/91940/pl atform-regopantes-jembatani-petanidengan-konsumen

Tumiwa, D. (2018, Juni 2). RegoPantes, Mendigitalkan Petani Kita. Diperoleh dari : https://kumparan.com/danieltumiwa1525778091610/regopantesmendigitalkan-petani-kita.

Widiastuti, R.N. (2018, September). Generasi Milenial Sebagai Audiens Kehumasan Pemerintah. Dipresentasikan pada Konferensi Nasional Penelitian dan Pengabdian Masyarakat Bidang Komunikasi (KNP2K), September 5-6, 2018. Jakarta

Wulandari, D. (2017). 8villages Indonesia Rilis Platform E-commerce RegoPantes. Diperoleh dari : http://mix.co.id/marcomm/newstrend/8villages-indonesia-rilis-platforme-commerce-regopantes

Wulandari, S.T. (2018, Mei 17) Wim Prihanto Jalan Keadilan Petani dan Konsumen. Diperoleh dari: http://mediaindonesia.com/read/detail/16 1256-wim-prihanto-jalan-keadilanpetani-dan-konsumen 